\title{
Base Materials' Influence on Fracture Resistance of Molars with MOD Cavities
}

\author{
Gabriela Ciavoi ${ }^{1,+}{ }^{+}$Ruxandra Mărgărit ${ }^{2,+}{ }^{,}$Liana Todor ${ }^{1, *}\left(\mathbb{D}\right.$, Dana Bodnar ${ }^{2}$, Magdalena Natalia Dina ${ }^{3}$, \\ Daniela Ioana Tărlungeanu ${ }^{4, *}$, Denisa Cojocaru ${ }^{5}$, Cătălina Farcaşiu ${ }^{6,+}$ and Oana Cella Andrei ${ }^{4}(\mathbb{D}$
}

1 Department of Dental Medicine, Faculty of Medicine and Pharmacy, University of Oradea,

10 1st December Square, 410068 Oradea, Romania; gciavoi@uoradea.ro

2 Department of Restorative Odontotherapy, Faculty of Dentistry, Carol Davila University of Medicine and Pharmacy, 37 Dionisie Lupu Str., 020021 Bucharest, Romania; ruxandra.margarit@gmail.com (R.M.); dana21bodnar@gmail.com (D.B.)

3 Department of Dental Techniques, Faculty of Midwifery and Nursing, Carol Davila University of Medicine and Pharmacy, 37 Dionisie Lupu Str., 020021 Bucharest, Romania; office@shinegrup.ro

4 Department of Removable Prosthodontics, Faculty of Dentistry, Carol Davila University of Medicine and Pharmacy, 37 Dionisie Lupu Str., 020021 Bucharest, Romania; cella.andrei@gmail.com

5 Independent Researcher, 020021 Bucharest, Romania; denisa.cojocaru96@yahoo.com

6 Faculty of Dentistry, Department of Pedodontics, Carol Davila University of Medicine and Pharmacy, 37 Dionisie Lupu Str., 020021 Bucharest, Romania; catalina.farcasiu@yahoo.com

* Correspondence: liana.todor@gmail.com (L.T.); ioanatarlungeanu@gmail.com (D.I.T.)

+ These authors contributed equally to this work.

Citation: Ciavoi, G.; Mărgărit, R.; Todor, L.; Bodnar, D.; Dina, M.N.; Tărlungeanu, D.I.; Cojocaru, D.; Farcaşiu, C.; Andrei, O.C. Base Materials' Influence on Fracture Resistance of Molars with MOD Cavities. Materials 2021, 14, 5242. https://doi.org/10.3390/ma14185242

Academic Editor: Andrea Spagnoli

Received: 14 July 2021

Accepted: 9 September 2021

Published: 12 September 2021

Publisher's Note: MDPI stays neutral with regard to jurisdictional claims in published maps and institutional affiliations.

Copyright: (c) 2021 by the authors. Licensee MDPI, Basel, Switzerland. This article is an open access article distributed under the terms and conditions of the Creative Commons Attribution (CC BY) license (https:// creativecommons.org/licenses/by/ $4.0 /)$.

\begin{abstract}
The aim of this study was to compare fracture resistance of teeth presenting medium-sized mesial-occlusal-distal (MOD) cavities using different base materials. Thirty-six extracted molars were immersed for $48 \mathrm{~h}$ in saline solution $\left(0.1 \%\right.$ thymol at $\left.4{ }^{\circ} \mathrm{C}\right)$ and divided into six groups. In group $\mathrm{A}$, the molars were untouched, and in group B, cavities were prepared, but not filled. In group $\mathrm{C}$, we used zinc polycarboxylate cement, in group $\mathrm{D}$-conventional glass ionomer cement, in group $\mathrm{E}$-resin modified glass ionomer cement, and in group $\mathrm{F}$-flow composite. Fracture resistance was tested using a universal loading machine (Lloyd Instruments) with a maximum force of $5 \mathrm{kN}$ and a crosshead speed of $1.0 \mathrm{~mm} / \mathrm{min}$; we used NEXYGEN Data Analysis Software and ANOVA Method $(p<0.05)$. The smallest load that determined the sample failure was $2780 \mathrm{~N}$ for Group A, 865 N for Group B, 1210 N for Group C, 1340 N for Group D, 1630 N for Group E and 1742 N for Group F. The highest loads were 3050 N (A), 1040 N (B), 1430 N (C), 1500 N (D), 1790 N (E), and $3320 \mathrm{~N}(\mathrm{~F})$, the mean values being $2902 \pm 114 \mathrm{~N}(\mathrm{~A}), 972 \pm 65 \mathrm{~N}(\mathrm{~B}), 1339 \pm 84 \mathrm{~N}(\mathrm{C}), 1415 \pm 67 \mathrm{~N}$ (D), $1712 \pm 62 \mathrm{~N}(\mathrm{E})$, and $2334 \pm 662 \mathrm{~N}(\mathrm{~F})$. A $p=0.000195$ shows a statistically significant difference between groups C, D, E and F. For medium sized mesial-occlusal-distal (MOD) cavities, the best base material regarding fracture resistance was flow composite, followed by glass ionomer modified with resin, conventional glass ionomer cement and zinc polycarboxylate cement. It can be concluded that light-cured base materials are a better option for the analyzed use case, one of the possible reasons being their compatibility with the final restoration material, also light-cured.
\end{abstract}

Keywords: mesial-occlusal-distal (MOD) cavities; fracture resistance; base materials

\section{Introduction}

Fractures of posterior teeth with mesial-occlusal-distal (MOD) cavities restored with different materials can occur in mastication more frequently than those of healthy ones, proportionally with the quantity of hard dental tissues loss [1-3]. As restoration materials, those that adhere most to the dentin are the most recommended [4], considering that using them increases the resistance of the restored tooth [5,6]. A material used as a base for replacing lost dentine in a medium-sized cavity ensures a uniformly distributed load and tension across the filled tooth [7], especially in MOD cavities [8,9]. Among the 
most used base materials are glass ionomer cements, zinc polycarboxylate cements, zinc phosphate cements and resins. Nowadays, composite resins are preferred for restoring MOD cavities [10], offering good esthetics for an acceptable price [11,12]. Some authors mostly recommend replacing dentin with a glass ionomer cement or a flow composite as a base material $[13,14]$. Glass ionomer cements adhere to dental structures because they develop an ion-enriched interfacial zone with dentine [15]; they present a minimum contraction setting and less marginal infiltration than most composite resins [16]. Their mechanical properties are moderate [17], but their cariostatic effect and adhesion to dentin recommend them as base materials. Zinc polycarboxylate cements present mechanical and adhesive properties similar to glass ionomer cements [18]. Better, such properties are gained by glass ionomer cements enriched with resins. Flow composites used as base materials present the advantage of good adherence to the composite restoration material. They can be applied in layers of up to $4 \mathrm{~mm}$ and they adapt perfectly to the form of the prepared cavity. Studies reported that using flow composites as base materials determined a decrease of tensions in the restored tooth in class II cavities [19,20]; the recommended final restoration material for such a base is a special composite resin for posterior teeth [21]. The aim of this study was to compare the fracture resistance of teeth presenting medium sized mesial-occlusal-distal (MOD) cavities filled with the same composite resin, but having different base materials, in order to find out which base material is best to use for the long-term resistance of tooth in mastication. Medium sized mesial-occlusal-distal cavities are those affecting both the enamel and the dentin, in consequence needing two layers of filling material, but far enough from the pulp so they do not require pulp capping. The interactions of the materials used in the experiment with the dental structures, elasticity modulus and compression strength values are presented in Table 1.

Table 1. Data regarding adhesion to the dental structures, elasticity modulus and compression strength.

\begin{tabular}{|c|c|c|c|}
\hline Material & Adhesion & $\begin{array}{l}\text { Modulus of } \\
\text { Elasticity }\end{array}$ & $\begin{array}{l}\text { Compression } \\
\text { Strength }\end{array}$ \\
\hline Adhesor carbofine (Spofa Dental) & Natural adhesion to the hard dental tissues & $4.4 \mathrm{GPa}$ & $47 \mathrm{MPa}$ \\
\hline Fuji IX (GC) & Intrinsic adhesion to dentine and enamel, without the need for etching and bonding & $8.3 \mathrm{GPa}$ & $220 \mathrm{MPa}$ \\
\hline Fuji II LC (GC) & Strong adhesion, excellent bond strength to teeth even in presence of saliva & $5.33 \mathrm{GPa}$ & $245 \mathrm{MPa}$ \\
\hline Charisma flow (Heraeus Kulzer) & Adhesive for any bonding technique & $14.3 \mathrm{GPa}$ & $325 \mathrm{MPa}$ \\
\hline Charisma (Heraeus Kulzer) & Adhesive for any bonding technique & $8 \mathrm{GPa}$ & $325 \mathrm{MPa}$ \\
\hline
\end{tabular}

\section{Materials and Methods}

\subsection{Preparation of Teeth}

We used 36 molars, extracted for orthodontic purposes, with no previous cavities or fillings, that were collected from 4 private clinics and divided into six groups (Group A-F) of six teeth each (Figure 1a). They were cleaned by removing the remnant soft tissues and immersed for $48 \mathrm{~h}$ in saline solution containing $0.1 \%$ thymol at $4{ }^{\circ} \mathrm{C}$, until the cavities were prepared, in order to avoid dehydration.

\subsection{Preparation of Test Specimens}

In the first of the six groups, the control group, the molars were kept untouched (Group A) (Figure 1b). In the teeth from the remaining five groups, mesial-occlusal-distal (MOD) medium sized cavities were prepared using the same burs at high speed, 30 identical round burs ISO 001/014 with a diameter of $1.4 \mathrm{~mm}$ and 30 identical cylindrical burs ISO 111/012 with a diameter of $1.2 \mathrm{~mm}$, two new burs for each prepared molar; the cavities' dimensions of $3.5 \mathrm{~mm}$ in width and $4.5 \mathrm{~mm}$ in height were verified using a digital caliper with an accuracy of $0.01 \mathrm{~mm}$ (Mitutoyo, Japan), cleaned and dried. In the second group, the medium-sized cavities were prepared, but were not filled at all, simulating a possible loss of the filling (Group B) (Figure 1c). In the other four groups, all final restorations were made with the same restoration material, using a universal composite (Charisma), but with four different types of base materials: Zinc polycarboxylate cement (zinc oxide with polyacrylic acid-metallic oxide-ZPC) for Group C, conventional glass ionomer cement (silicate 
glass powder and polyacrylic acid-GIC) for Group D, resin modified glass ionomer cement (hybrid materials of traditional glass ionomer cement with a small addition of light-curing resin-RMGIC) for Group E, and flow composite (flowable resin-based composites that are conventional composites with the filler loading reduced to $37-53 \%$ in volume-FC) for Group $\mathrm{F}$ (Table 2). The chemical composition of the materials used for the experiment is presented in Table 2. All fillings were done according to the manufacturer's recommendations; the setting time was respected for all the materials used: 5-8 min for Adhesor carbofine, 6 min for Fuji IX and $20 \mathrm{~s}$ for the two light-cured materials.

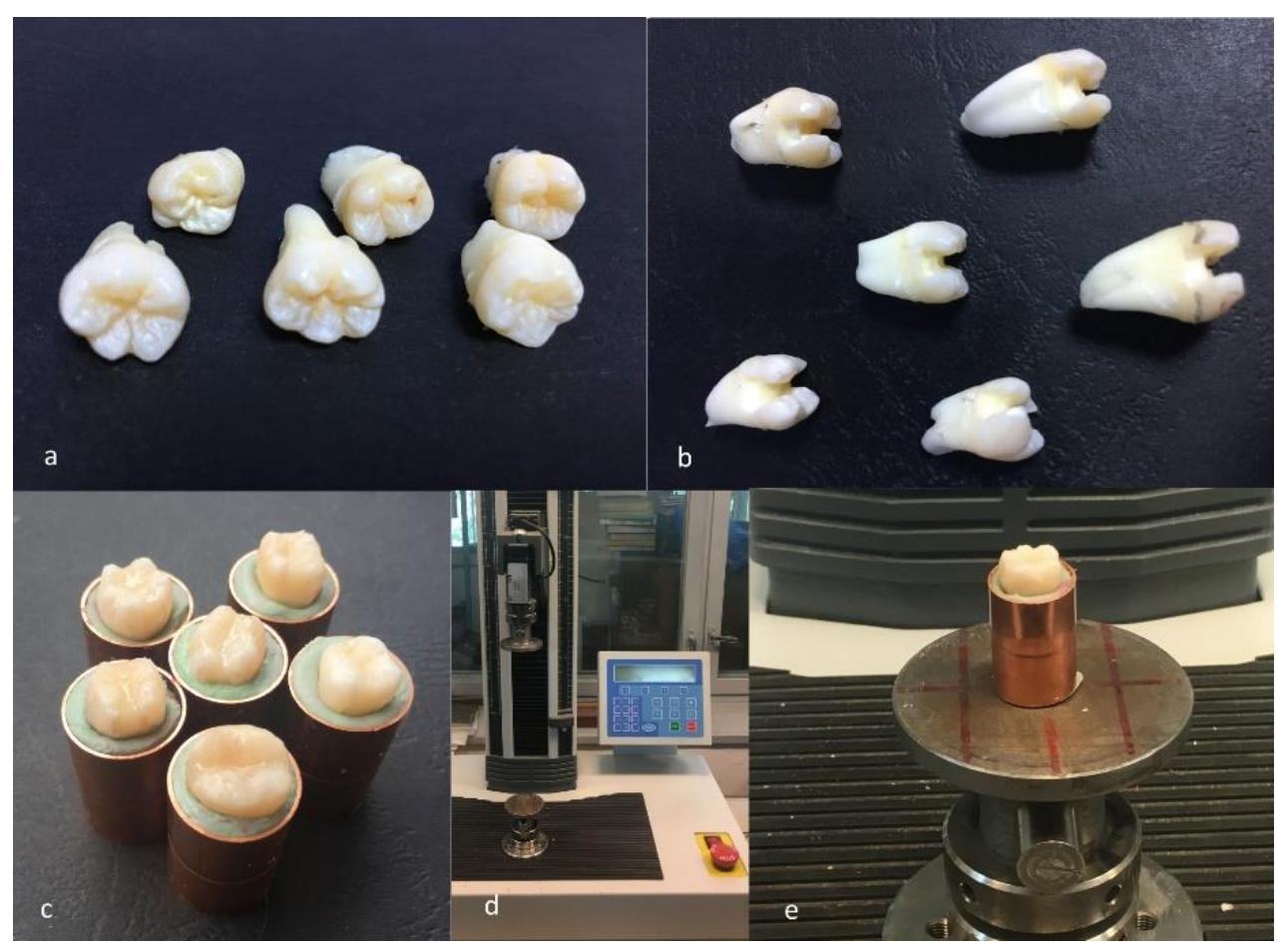

Figure 1. (a) Group of six molars unprepared; (b) group of six molars with MOD cavities; (c) group of samples prepared for testing; (d) universal loading machine; and (e) specimen before testing.

Table 2. The materials used for teeth restoration.

\begin{tabular}{|c|c|c|c|}
\hline Material & Purpose & Type & Chemical Composition \\
\hline $\begin{array}{c}\text { Adhesor } \\
\text { carbofine } \\
\text { (Spofa Dental) }\end{array}$ & Base & ZPC—zinc polycarboxylate cement & $\begin{array}{l}\text { Zinc oxide, magnesium oxide, aluminum oxide, boric } \\
\text { acid, acrylic acid, maleic anhydride, distilled water }\end{array}$ \\
\hline Fuji IX (GC) & Base & GIC_-glass ionomer cement & Alumino-silicate glass $95 \%$, polyacrylic acid powder $5 \%$ \\
\hline Fuji II LC (GC) & Base & $\begin{array}{l}\text { RMGIC- Light-cured Resin } \\
\text { Reinforced Glass Ionomer cement }\end{array}$ & $\begin{array}{c}\text { Fluoro-alumino-silicate glass, polyacrylic acid 30-35\%, } \\
\text { distilled water } 20-30 \% \text {, } 2 \text { HEMA } 25-30 \% \text {, initiator, } \\
\text { urethan dymethylacrylate, camphorquinone } \\
\text { multifunctional methacrylate monomers }\end{array}$ \\
\hline $\begin{array}{l}\text { Charisma flow } \\
\text { (Heraeus Kulzer) }\end{array}$ & Base & $\begin{array}{l}\text { FC-Flowable resin-micro-hybrid } \\
\text { flowable composite, Light-cured }\end{array}$ & $\begin{array}{c}\text { (EBADMA/TEGDMA); contains approximately } 62 \% \text { by } \\
\text { weight or } 38 \% \text { by volume inorganic fillers such as } \\
\text { Ba-AI-F silicate glass and } \mathrm{SiO}_{2} \text {. The filler particle size is } \\
\text { between } 0.005 \mu \mathrm{m} \text { and } 5 \mu \mathrm{m} \text {. }\end{array}$ \\
\hline $\begin{array}{c}\text { Charisma } \\
\text { (Heraeus Kulzer) }\end{array}$ & $\begin{array}{l}\text { Final } \\
\text { restoration }\end{array}$ & $\begin{array}{l}\text { Universal hybrid composite with } \\
\text { microparticles, Light-cured }\end{array}$ & $\begin{array}{l}\text { BIS-GMA matrix; contains } 64 \% \text { filler by volume: barium } \\
\text { aluminum fluoride glass ( } 0.02-2 \text { microns); colloidal } \\
\text { silica }-0.01-0.07 \mu \mathrm{m} .\end{array}$ \\
\hline
\end{tabular}

For this experiment, the roots of the teeth were introduced in 36 identical cylindricalshaped containers filled with a putty silicone material, in order to resiliently support them during the experiment and to mimic the oral cavity conditions (Figure 1c). 


\subsection{Fracture Resistance Test}

Fracture resistance was tested using a universal loading machine (Lloyd Instruments, Segensworth, Fareham, UK) (Figure 1d); samples were subjected to vertical compression, with a maximum force of $5 \mathrm{kN}$ and a crosshead speed of $1.0 \mathrm{~mm} / \mathrm{min}$ until the fracture of the tooth; the results were recorded with NEXYGEN Plus 3 Data Analysis Software. A representative specimen is shown in Figure 1e. The graphics show data regarding the maximum fracture force values till the fracture of the most resistant specimen of each group.

\subsection{Statistical Analysis}

Statistical analysis of obtained experimental values was performed using Microsoft Excel and ANOVA Method. For the variability of measured forces, mean values and standard deviations were analyzed. The level of significance was set at $p<0.05$.

\section{Results}

For each group, the test results for each molar, the mean fracture force, median and the standard deviation are expressed in Table 3 . The graphs with the maximum value of the force in which the most resistant sample from each group failed is represented in Figures 2-7. Group A, the control group, was stronger than all other groups, with a mean value of $2902 \pm 114$ N. Group B was weaker than all other groups, with a mean value of $972 \pm 65 \mathrm{~N}$. Group C and D were rather similar in terms of fracture resistance, with mean values of $1339 \pm 84 \mathrm{~N}$ and $1415 \pm 67 \mathrm{~N}$. A more relevant difference was found between groups $\mathrm{E}$ and F, with mean values of $1712 \pm 62 \mathrm{~N}$ and $2334 \pm 662 \mathrm{~N}$. In order to better compare the results for the four base materials that were used, the overlaid graphs of groups $\mathrm{C}-\mathrm{F}$ are represented in Figure 8.

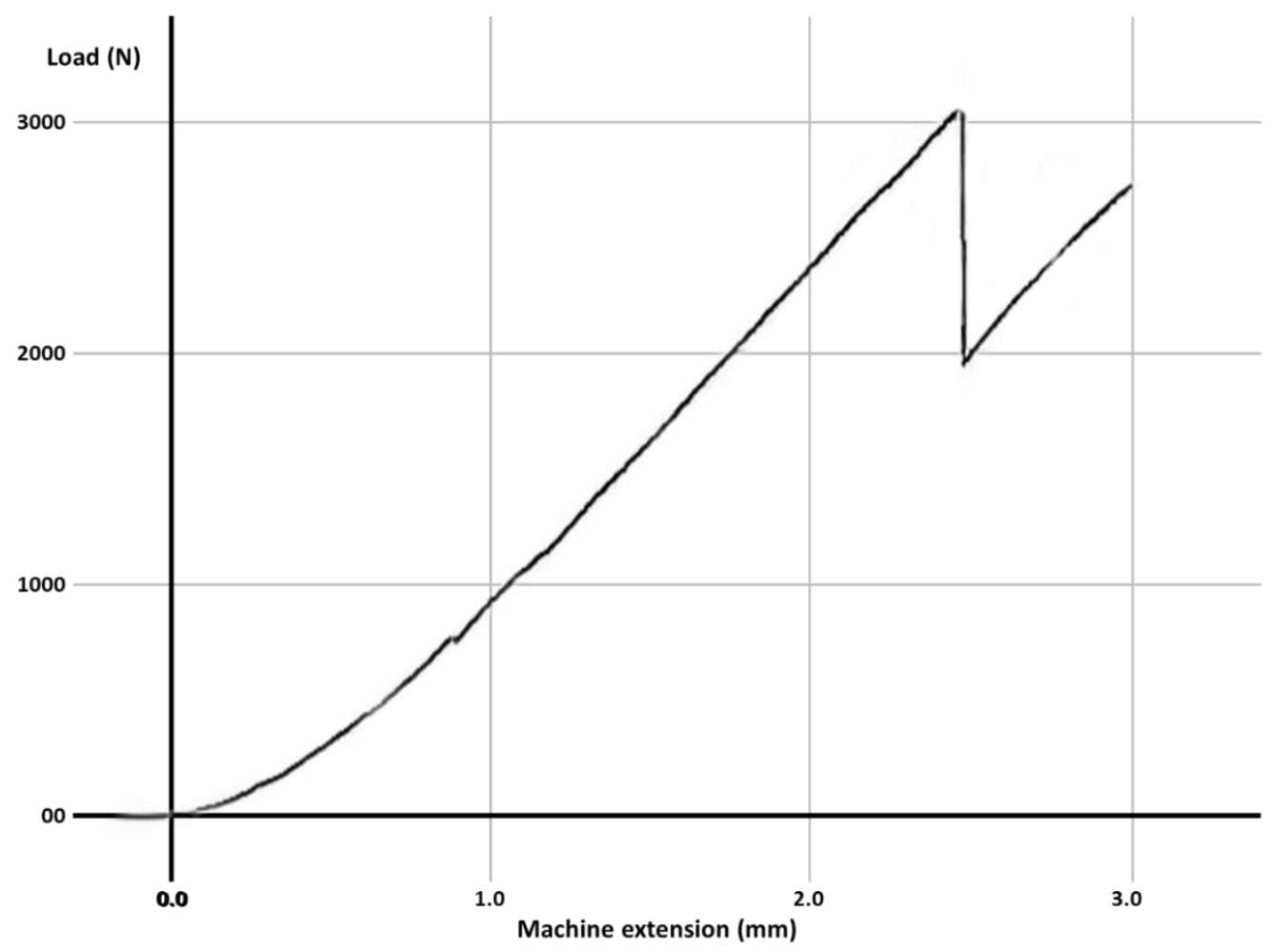

Figure 2. The maximum value of the force at which the most resistant molar from Group A failed. 


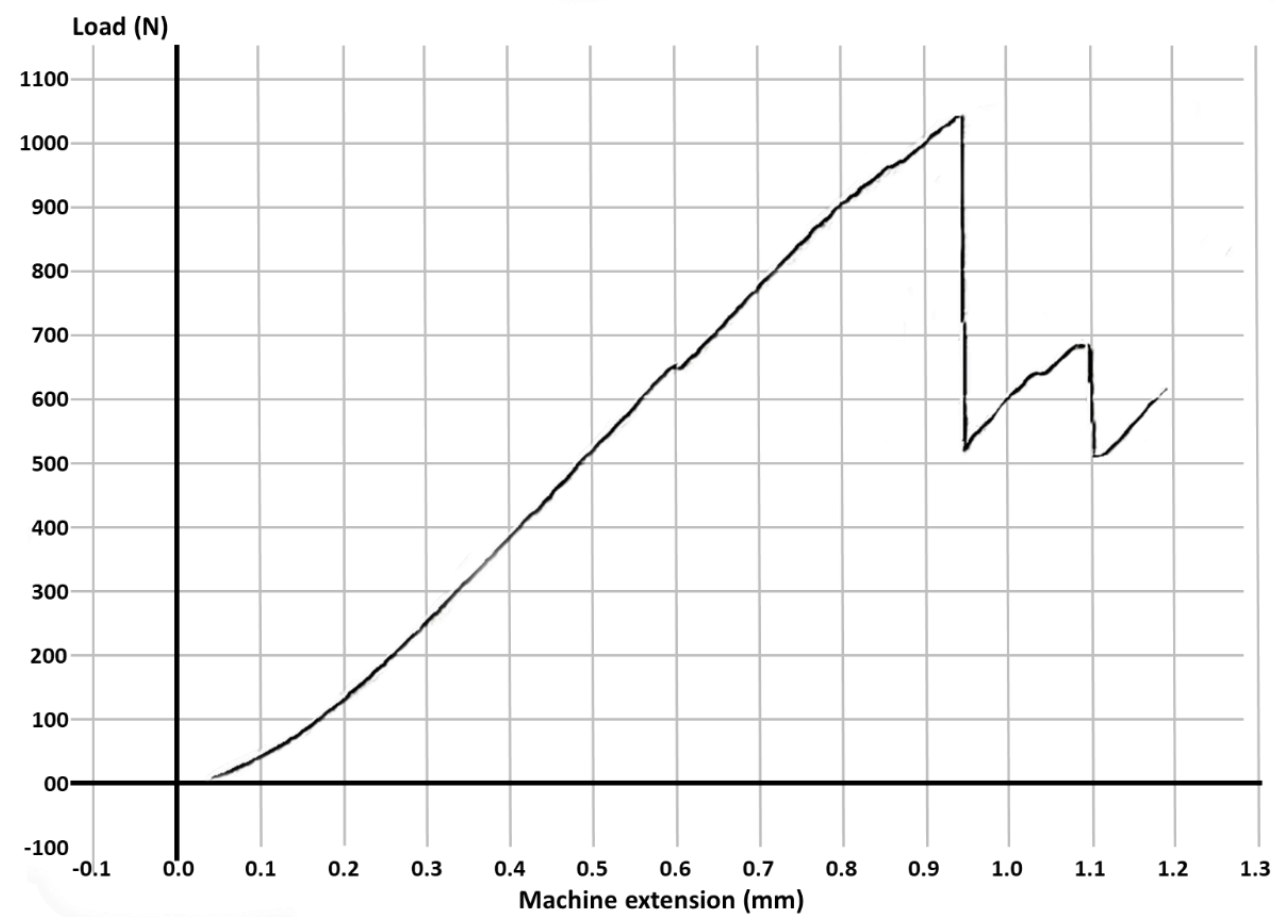

Figure 3. The maximum value of the force at which the most resistant molar from Group B failed.

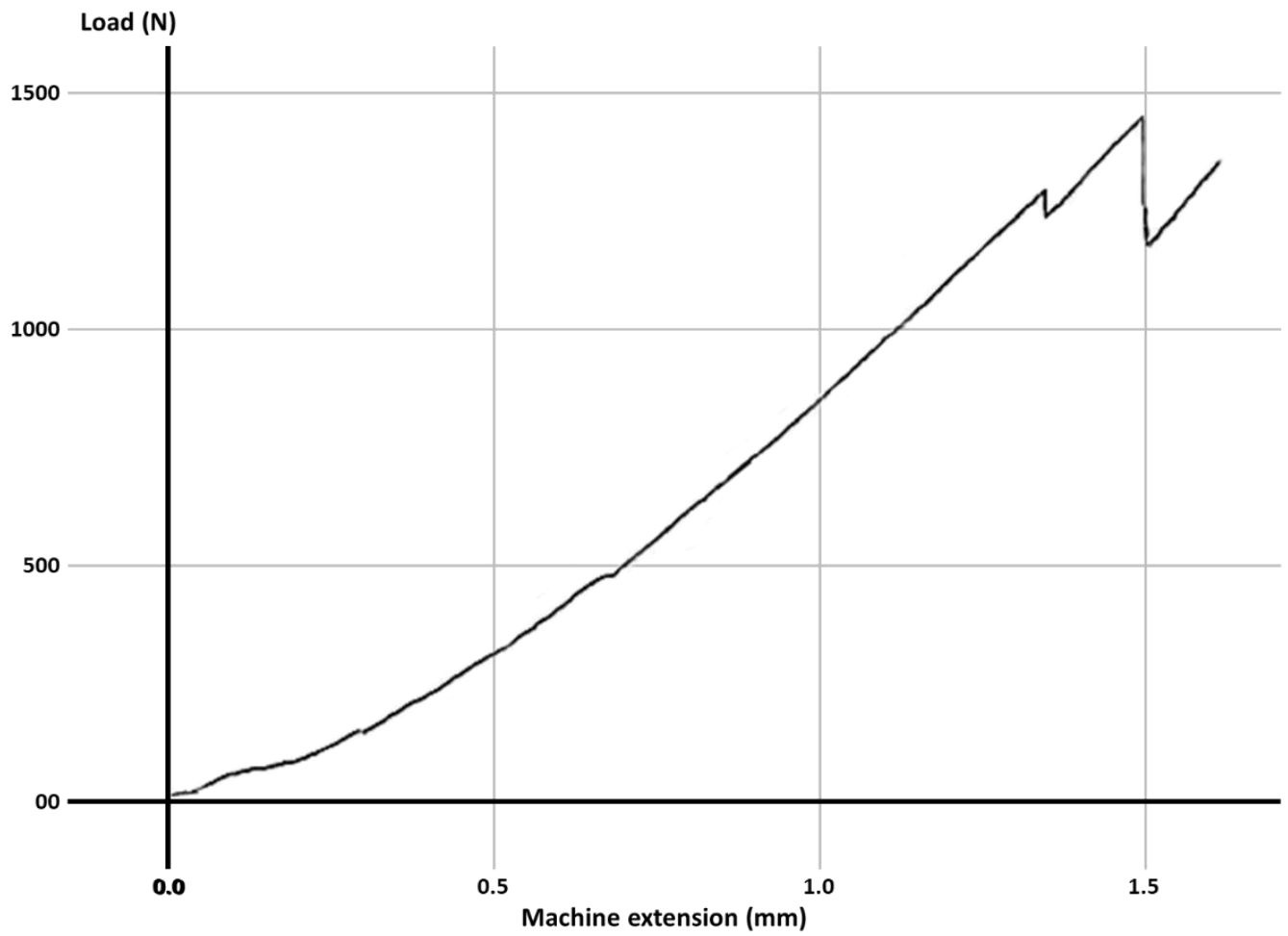

Figure 4. The maximum value of the force at which the most resistant molar from Group $C$ failed. 


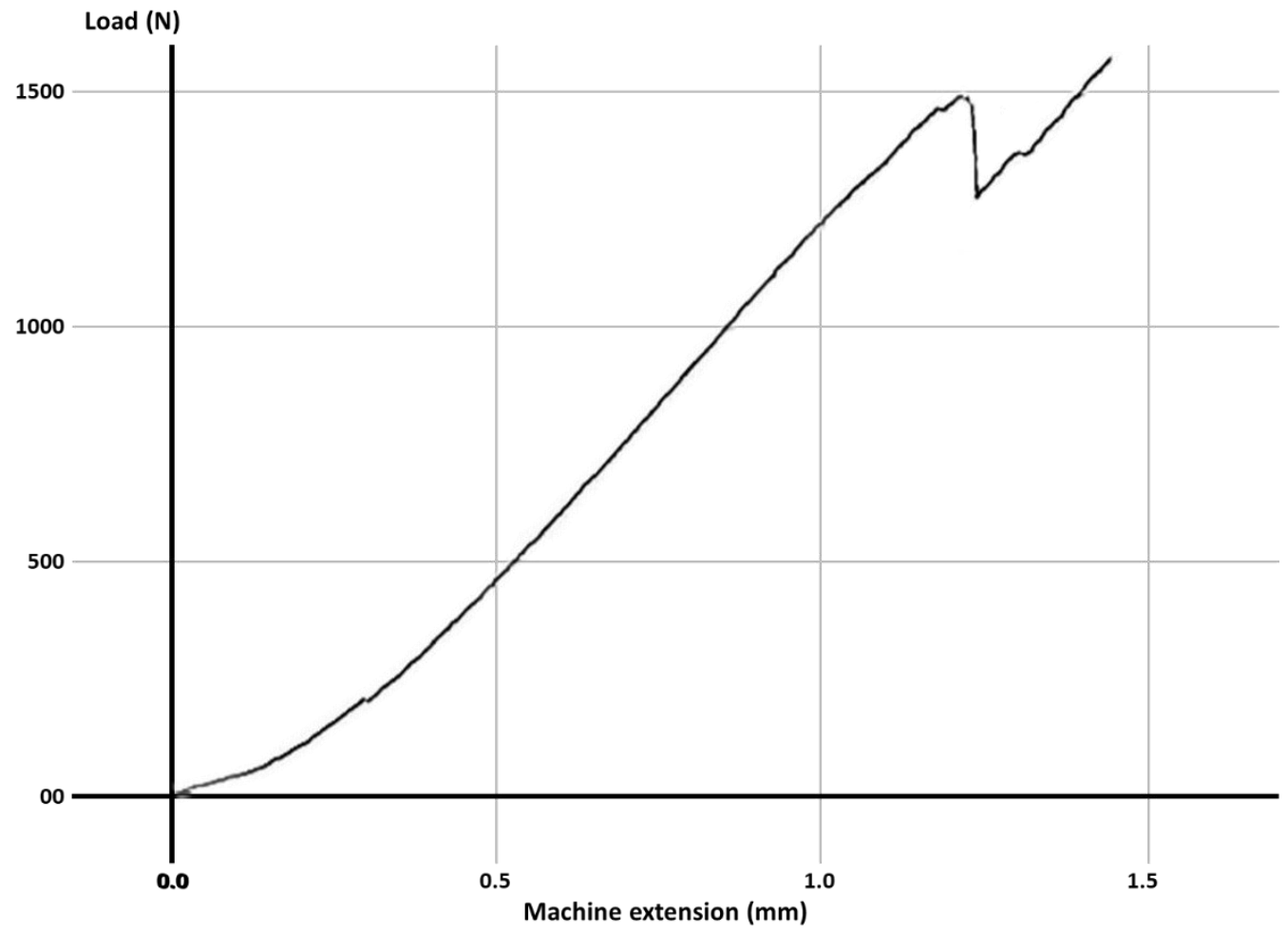

Figure 5. The maximum value of the force at which the most resistant molar from Group D failed.

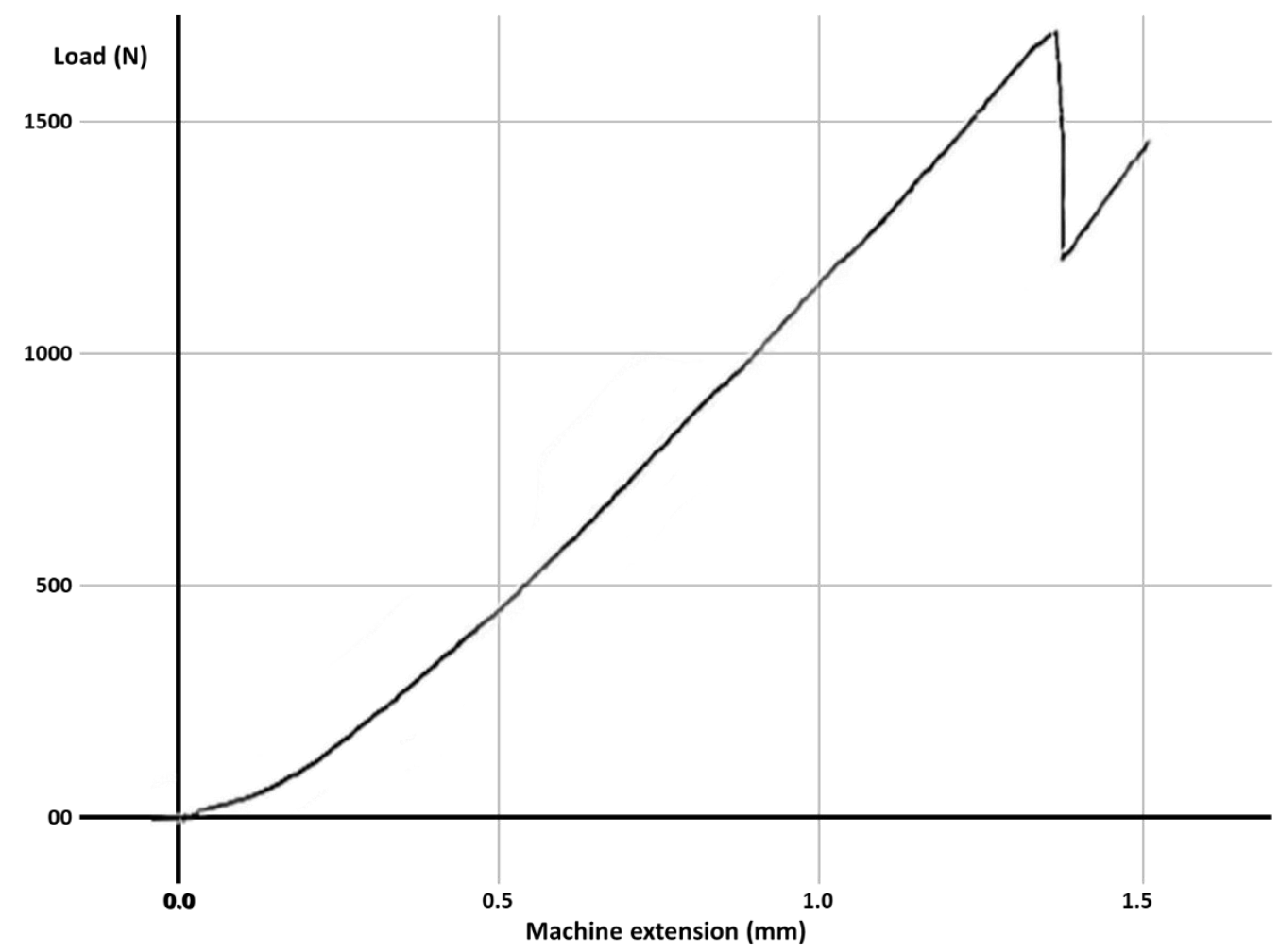

Figure 6. The maximum value of the force at which the most resistant molar from Group E failed. 


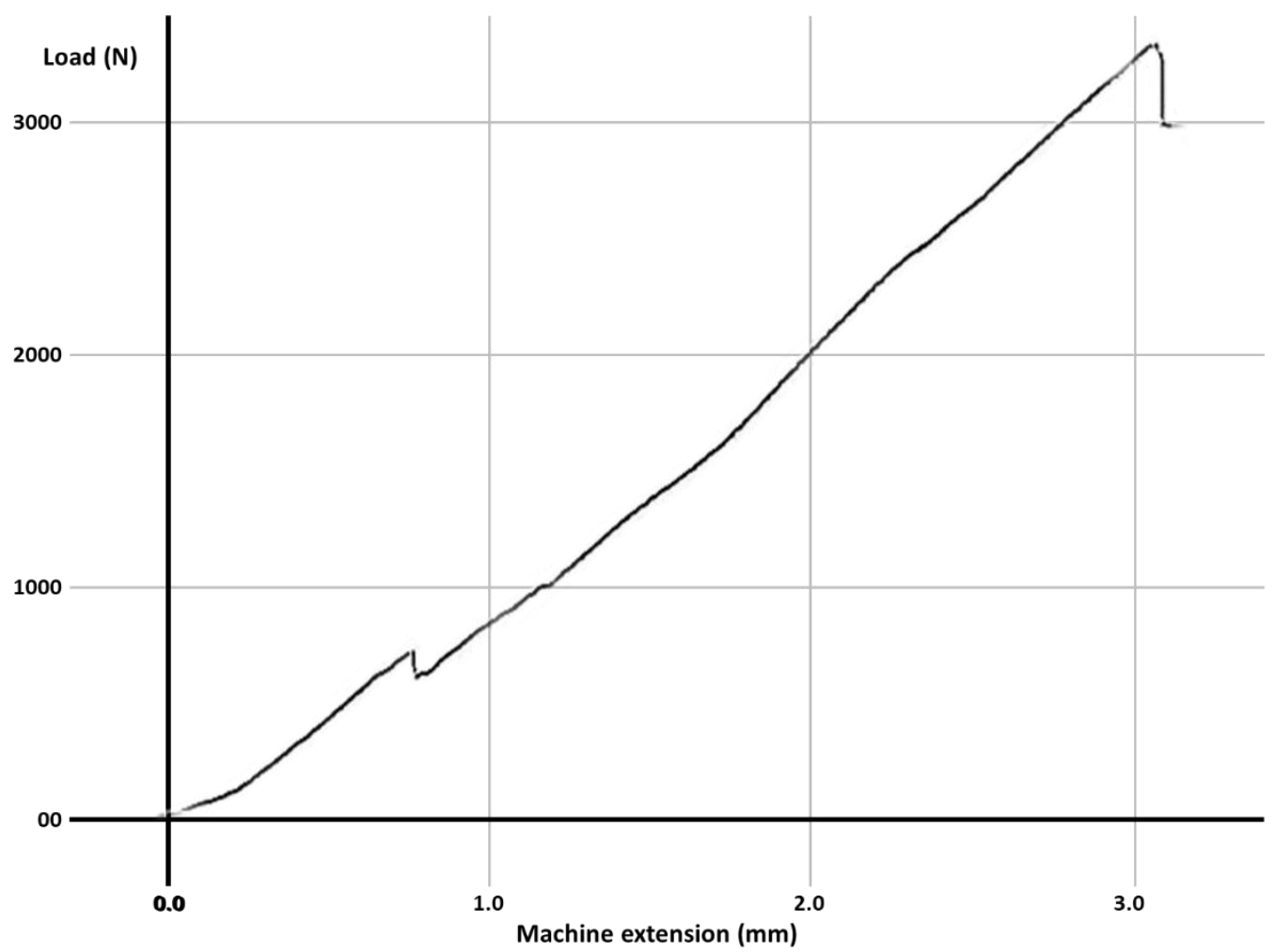

Figure 7. The maximum value of the force at which the most resistant molar from Group F failed.

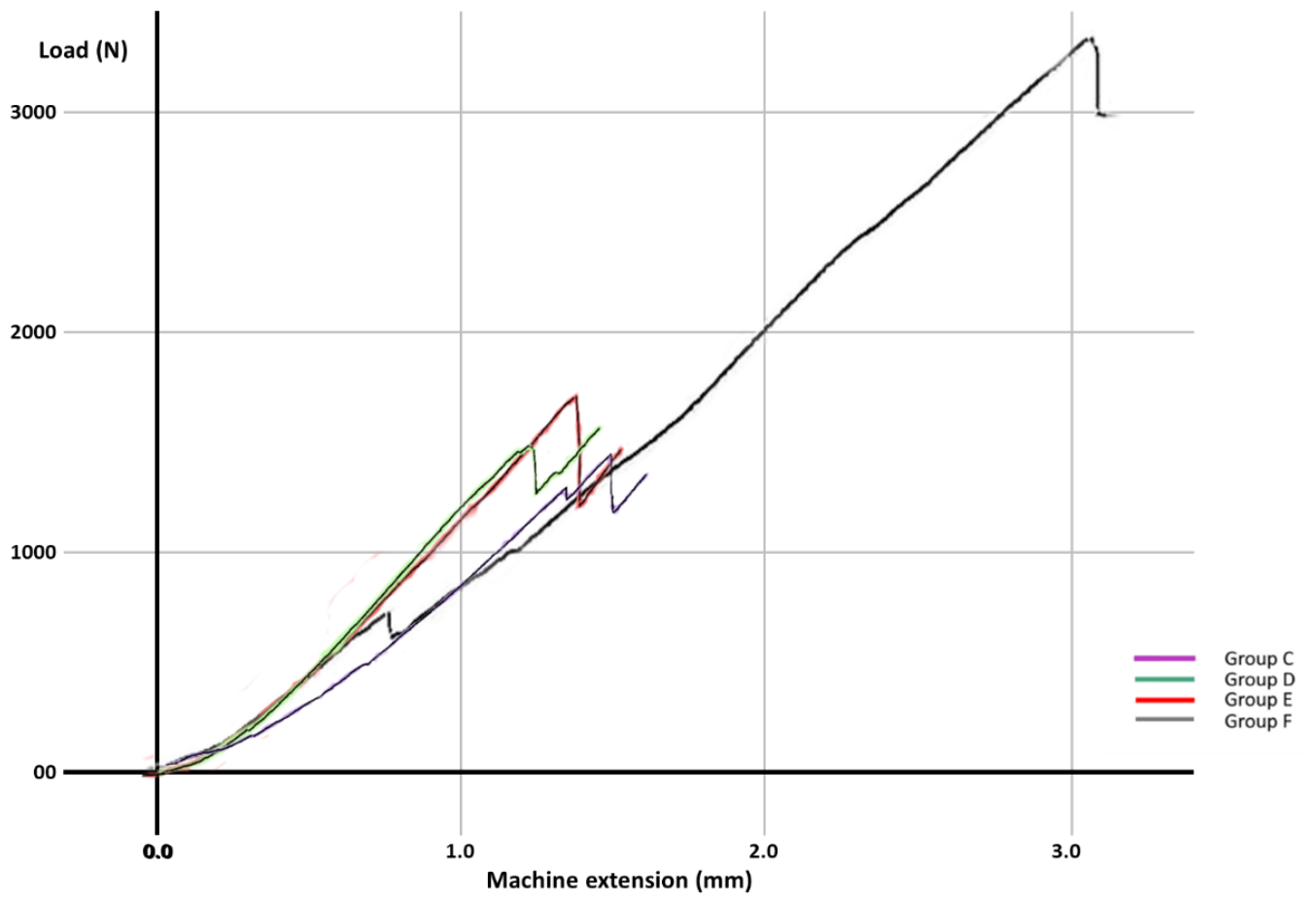

Figure 8. Result comparison for Groups C-F. 
Table 3. The maximum force values at which the teeth in each of the six groups fractured.

\begin{tabular}{cccccccccc}
\hline \multirow{2}{*}{ Group } & Mean (N) & \multirow{2}{*}{$\begin{array}{c}\text { Standard } \\
\text { Deviation }\end{array}$} & Median & \multicolumn{4}{c}{ Fracture Force (N) for Each Specimen } \\
\cline { 5 - 9 } & & & $\mathbf{1}$ & $\mathbf{2}$ & $\mathbf{3}$ & $\mathbf{4}$ & $\mathbf{5}$ & $\mathbf{6}$ \\
\hline A & 2902 & 114 & 2889 & 2780 & 2795 & 2835 & 2943 & 3010 & 3050 \\
B & 972 & 65 & 988 & 865 & 930 & 972 & 1004 & 1025 & 1040 \\
C & 1339 & 84 & 1348 & 1210 & 1286 & 1315 & 1382 & 1413 & 1430 \\
D & 1415 & 67 & 1408 & 1340 & 1358 & 1372 & 1445 & 1478 & 1500 \\
E & 1712 & 62 & 1716 & 1630 & 1655 & 1698 & 1734 & 1765 & 1790 \\
F & 2334 & 662 & 2112 & 1742 & 1795 & 1855 & 2370 & 2925 & 3320 \\
\hline
\end{tabular}

Statistical analysis using the ANOVA method in order to understand the relevance of the study revealed a $p$ value of 0.000195 , showing a statistically significant difference between Groups C-F restored with four different types of base materials (Table 4).

Table 4. ANOVA Method and $p$ value.

\begin{tabular}{|c|c|c|c|c|c|c|}
\hline \multicolumn{7}{|c|}{ ANOVA: Single Factor } \\
\hline \multicolumn{7}{|c|}{ SUMMARY } \\
\hline Groups & Count & Sum & Average & & Variance & \\
\hline $\mathrm{C}-\mathrm{ZPC}$ & 6 & 8036 & 1339.333 & & 7126.267 & \\
\hline D-GIC & 6 & 8493 & 1415.5 & & 4563.1 & \\
\hline E-RMGIC & 6 & 10,272 & 1712 & & 3909.2 & \\
\hline F-FC & 6 & 14,007 & 2334.5 & & $438,639.5$ & \\
\hline \multicolumn{7}{|l|}{ ANOVA } \\
\hline Source of Variation & SS & df & MS & F & $p$-Value & F Crit \\
\hline Between Groups & $3,682,527$ & 3 & $1,227,509$ & 10.80939 & & \\
\hline Within Groups & $2,271,190$ & 20 & $113,559.5$ & & & \\
\hline Total & $5,953,717$ & 23 & & & & \\
\hline
\end{tabular}

\section{Discussion}

Choosing the base material for medium-sized MOD cavities is difficult, because it can influence the long-term prognostic of the restored tooth. These cavities are involving both enamel and dentin; reducing the quantity of the dental tissues is a predisposing factor for fracture [1]. Studies reported that teeth with MOD cavities are losing their resistance in a proportion of $60 \%$, compared to the non-prepared ones [22]. It has been reported that most recommended base materials for ensuring fracture resistance of the tooth are the ones presenting an elasticity modulus similar with the one of the dentin, such as composite resins [23,24], while the elasticity modulus of the zinc polycarboxylate cements and glass ionomer cements is smaller than that of the composite resins [25-27]. Some studies reported that using a base material with a low elasticity modulus presents the advantage of a higher deformation under occlusal forces, which reduces the fracture risk, while another study analyzing fracture resistance of non-vital teeth restored with different base materials showed that their different elasticity modulus did not influence fracture resistance of the teeth at all [28].

Other authors reported that conventional glass ionomer cement used as a base material had a positive influence on fracture resistance, teeth restored in such manner having a similar fracture resistance to the non-prepared ones [29,30]. Another study showed that glass ionomer cements used as base absorbed tensions generated during setting of the composite fillings [31]. Other authors showed that for non-vital teeth using glass ionomer cements as a base did not increase the fracture resistance [32,33], while another study concluded that using conventional glass ionomer cements as a base in MOD cavities can increase the resistance [34]. Eakle analyzed fracture resistance of adherent filling materials and showed that, although conventional glass ionomers have inferior mechanical properties 
compared to composite resins, using them as restoration materials did not decrease fracture resistance of the restored teeth [35]. Compared to conventional ones, new glass ionomers that are enriched with resins offer a better working time, due to the possibility to control the polymerization. The results of the study made by Oz et al. showed that the best fracture resistance was that of the teeth restored with MOD fillings that had bases of glass ionomer modified with resins, compared to conventional glass ionomers and flow composites [36]. Still, the results obtained by Taha et al. in a study on non-vital teeth having flow composite as a base showed that, using these materials, the fracture resistance of those teeth improved [37]; similarly, other studies observed the smallest fracture resistance for glass ionomer cements used as base, and the highest for flow composites [38-41]. In our study, the best fracture resistance was also obtained for the group having flow composite as a base, glass ionomer cements modified with resins being in the middle.

Using a base material under an adhesive composite filling increases the fracture resistance of the restored non-vital teeth [3,32,42]; still, the excessive thickness of the base has a negative influence on it [43]. Other studies showed that in case of teeth with massive loss of hard dental tissues the higher tensions appear in the remaining dental tissues and not to the interface between tooth and restoration, so the tooth can suffer a fracture [44,45]. In our in vitro experiment, the teeth were prepared in such manner that the resulting MOD cavities were medium-sized; within these limits, the highest fracture resistance was obtained using the flow composite as a base material. Additionally, our results showed that any restoration of teeth increased their fracture resistance, compared to the absence of the fillings. Further tests are necessary in order to assess how the results may change in case of larger, more profound cavities.

\section{Conclusions}

Regardless of the materials chosen for this study, the results showed that untouched molars (Group A) had the best fracture resistance, with much higher values obtained compared to the filled ones; also, the prepared but not filled at all molars (Group B) had the lowest values of all groups, showing that lost and not replaced fillings expose molars to significantly higher fracture risks. These results underline once more the importance of monitoring and prevention, especially in countries with poor or limited insurance systems. Within the limits of this study, for medium size mesial-occlusal-distal (MOD) cavities, filled with composite resins, the best base material that can be used in terms of fracture resistance proved to be the flow composite, followed by the glass ionomer modified with resin, and by the conventional glass ionomer cement. The smallest fracture resistance was obtained using zinc polycarboxylate cement as a base. It can be concluded that light-cured base materials are a better option for the analyzed use case, one of the possible reasons being their compatibility with the final restoration material, also light-cured.

Author Contributions: Conceptualization, G.C., R.M. and O.C.A.; methodology, C.F.; software, D.B., M.N.D. and D.C.; validation, D.I.T. and L.T.; formal analysis M.N.D.; investigation L.T.; supervision, O.C.A.; data curation D.B., D.C. and R.M.; writing - original draft preparation G.C. and C.F.; writingreview and editing, D.I.T. and O.C.A. All authors have read and agreed to the published version of the manuscript.

Funding: This research received no external funding.

Institutional Review Board Statement: Not applicable.

Informed Consent Statement: Not applicable.

Data Availability Statement: Data is contained within the article.

Conflicts of Interest: The authors declare no conflict of interest.

Sample Availability: Samples are not available from the authors. 


\section{References}

1. Nam, S.H.; Chang, H.S.; Min, K.S.; Lee, Y.; Cho, H.W.; Bae, J.M. Effect of the number of residual walls on fracture resistances, failure patterns, and photoelasticity of simulated premolars restored with or without fiber-reinforced composite posts. J. Endod. 2010, 36, 297-301. [CrossRef] [PubMed]

2. Meng, Q.F.; Chen, Y.M.; Guang, H.B.; Yip, K.H.; Smales, R.J. Effect of a ferrule and increased clinical crown length on the in vitro fracture resistance of premolars restored using two dowel-and-core systems. Oper. Dent. 2007, 32, 595-601. [CrossRef] [PubMed]

3. Soares, P.V.; Santos-Filho, P.C.; Martins, L.R.; Soares, C.J. Influence of restorative technique on the biomechanical behavior of endodontically treated maxillary premolars. Part I: Fracture resistance and fracture mode. J. Prosthet. Dent. 2008, 99, 30-37. [CrossRef]

4. Sorrentino, R.; Aversa, R.; Ferro, V.; Auriemma, T.; Zarone, F.; Ferrari, M.; Apicella, A. Three-dimensional finite element analysis of strain and stress distributions in endodontically treated maxillary central incisors restored with different post, core and crown materials. Dent. Mater. 2007, 23, 983-993. [CrossRef]

5. Mărgărit, R.; Suciu, I.; Bodnar, D.C.; Grigore, M.; Scărlătescu, S.A.; Andrei, O.C.; Măgureanu, C.M.; Chirilă, M.; Bencze, A.; Ionescu, E. Fracture resistance of molars with MOD cavities restored with different materials. Rom. Biotechnol. Lett. 2021, 26, 2323-2330. [CrossRef]

6. Mărgărit, R.; Tănăsescu, L.A.; Bodnar, D.; Ion, C.G.; Burlibaşa, M.; Bisoc, A.; Farcaşiu, C.; Dina, M.N.; Andrei, O.C. Comparison of fracture resistance of teeth presenting non-carious cervical lesions, restored with different composite materials. Mater. Plast. 2020, 57, 299-305. [CrossRef]

7. Soares, P.V.; Santos-Filho, P.C.; Gomide, H.A.; Araujo, C.A.; Martins, L.R.; Soares, C.J. Influence of restorative technique on the biomechanical behavior of endodontically treated maxillary premolars. Part II: Strain measurement and stress distribution. J. Prosthet. Dent. 2008, 99, 114-122. [CrossRef]

8. Krämer, N.; Reinelt, C.; Frankenberger, R. Ten-year clinical performance of posterior resin composite restorations. J. Adhes. Dent. 2015, 17, 433-441.

9. Pallesen, U.; Van Dijken, J.W. A randomized controlled 30 years follow up of three conventional resin composites in class II restorations. Dent. Mater. 2015, 31, 1232-1244. [CrossRef]

10. Eskitaşcioğlu, G.; Belli, S.; Kalkan, M. Evaluation of two post core systems using two different methods (fracture strength test and a finite elemental stress analysis). J. Endod. 2002, 28, 629-633. [CrossRef]

11. Mondelli, R.F.; Ishikiriama, S.K.; De Oliveira Filho, O.; Mondelli, J. Fracture resistance of weakened teeth restored with condensable resin with and without cusp coverage. J. Appl. Oral Sci. 2009, 17, 161-165. [CrossRef]

12. Plotino, G.; Buono, L.; Grande, N.M.; Lamorgese, V.; Somma, F. Fracture resistance of endodontically treated molars restored with extensive composite resin restorations. J. Prosthet. Dent. 2008, 99, 225-232. [CrossRef]

13. Alomari, Q.D.; Reinhardt, J.W.; Boyer, D.B. Effect of liners on cusp deflection and gap formation in composite restorations. Oper. Dent. 2001, 26, 406-411.

14. Cho, E.; Chikawa, H.; Kishikawa, R.; Inai, N.; Otsuki, M.; Foxton, R.M.; Tagami, J. Influence of elasticity on gap formation in a lining technique with flowable composite. Dent. Mater. J. 2006, 25, 538-544. [CrossRef]

15. Yoshida, Y.; Van Meerbeek, B.; Nakayama, Y.; Snauwaert, J.; Hellemans, L.; Lambrechts, P.; Vanherle, G.; Wakasa, K. Evidence of chemical bonding at biomaterial-hard tissue interfaces. J. Dent. Res. 2000, 79, 709-714. [CrossRef]

16. Feilzer, A.J.; De Gee, A.J.; Davidson, C.L. Curing contraction of composites and glass-ionomer cements. J. Prosthet. Dent. 1988, 59, 297-300. [CrossRef]

17. Kovarik, R.E.; Breeding, L.C.; Caughman, W.F. Fatigue life of three core materials under simulated chewing conditions. J. Prosthet. Dent. 1992, 68, 584-590. [CrossRef]

18. Jemt, T.; Stalblad, P.A.; Øilo, G. Adhesion of polycarboxylate- based dental cements to enamel: An in vivo study. J. Dent. Res. 1986, 65, 885-887. [CrossRef]

19. Cara, R.R.; Fleming, G.J.; Palin, W.M.; Walmsley, A.D.; Burke, F.J. Cuspal deflection and microleakage in premolar teeth restored with resin-based composites with and without an intermediary flowable layer. J. Dent. 2007, 35, 482-489. [CrossRef]

20. Roggendorf, M.J.; Kramer, N.; Appelt, A.; Naumann, M.; Frankenberger, R. Marginal quality of flowable 4-mm base vs. conventionally layered resin composite. J. Dent. 2011, 39, 643-647. [CrossRef] [PubMed]

21. Ilie, N.; Bucuta, S.; Draenert, M. Bulk-fill resin-based composites: An in vitro assessment of their mechanical performance. Oper. Dent. 2013, 38, 618-625. [CrossRef]

22. Taha, N.A.; Palamara, J.E.; Messer, H.H. Fracture strength and fracture patterns of root filled teeth restored with direct resin restorations. J. Dent. 2011, 39, 527-535. [CrossRef] [PubMed]

23. Jiang, W.; Bo, H.; Yongchun, G.; Longxing, N. Stress distribution in molars restored with inlays or onlays with or without endodontic treatment: A three-dimensional finite element analysis. J. Prosthet. Dent. 2010, 103, 6-12. [CrossRef]

24. Kinney, J.H.; Marshall, S.J.; Marshall, G.W. The mechanical properties of human dentin: A critical review and re-evaluation of the dental literature. Crit. Rev. Oral Biol. Med. 2003, 14, 13-29. [CrossRef] [PubMed]

25. Tam, L.E.; Pulver, E.; Mccomb, D.; Smith, D.C. Physical properties of calcium hydroxide and glass-ionomer base and lining materials. Dent. Mater. 1989, 5, 145-149. [CrossRef]

26. Akinmade, A.O.; Hill, R.G. Influence of cement layer thickness on the adhesive bond strength of polyalkenoate cements. Biomater 1992, 13, 931-936. [CrossRef] 
27. Natale, L.; Rodrigues, M.; Xavier, T.; Simoes, A.; De Souza, D.; Braga, R. Ion release and mechanical properties of calcium silicate and calcium hydroxide materials used for pulp capping. Int. Endod. J. 2015, 48, 89-94. [CrossRef]

28. Chan, T.; Kucukkaya Eren, S.; Wong, R.; Parashos, P. In vitro fracture strength and patterns in root-filled teeth restored with different base materials. Aust. Dent. J. 2018, 63, 99-108. [CrossRef]

29. Hernandez, R.; Bader, S.; Boston, D.; Trope, M. Resistance to fracture of endodontically treated premolars restored with new generation dentine bonding systems. Int. Endod. J. 1994, 27, 281-284. [CrossRef] [PubMed]

30. Wendt, S.L., Jr.; Harris, B.M.; Hunt, T.E. Resistance to cusp fracture in endodontically treated teeth. Dent. Mater. 1987, 3, $232-235$. [CrossRef]

31. Davidson, C.L. Glass-ionomer bases under posterior composites. J. Esthet. Dent. 1994, 6, 223-224. [CrossRef]

32. Taha, N.A.; Palamara, J.E.; Messer, H.H. Assessment of laminate technique using glass ionomer and resin composite for restoration of root filled teeth. J. Dent. 2012, 40, 617-623. [CrossRef]

33. Trope, M.; Tronstad, L. Resistance to fracture of endodontically treated premolars restored with glass ionomer cement or acid etch composite resin. J. Endod. 1991, 17, 257-259. [CrossRef]

34. Banomyong, D.; Harnirattisai, C.; Burrow, M.F. Posterior resin composite restorations with or without resin-modified, glassionomer cement lining: A 1-year randomized, clinical trial. J. Investig. Clin. Dent. 2011, 2, 63-69. [CrossRef]

35. Eakle, W.S. Increased fracture resistance of teeth: Comparison of five bonded composite resin systems. Quintessence Int. 1986, 17, 17-20.

36. Oz, F.D.; Ergin, E.; Gurgan, S. Comparison of different base materials on fracture strength of mesio-occlusal-distal composite restorations. Eur. J. Gen. Dent. 2018, 7, 25-30. [CrossRef]

37. Taha, N.A.; Maghaireh, G.A.; Ghannam, A.S.; Palamara, J.E. Effect of bulk-fill base material on fracture strength of root-filled teeth restored with laminate resin composite restorations. J. Dent. 2017, 63, 60-64. [CrossRef]

38. Ilie, N.; Hickel, R.; Valceanu, A.S.; Huth, K.C. Fracture toughness of dental restorative materials. Clin. Oral Investig. 2012, 16, 489-498. [CrossRef] [PubMed]

39. Rosatto, C.M.; Bicalho, A.A.; Verissimo, C.; Braganca, G.F.; Rodrigues, M.P.; Tantbirojn, D.; Versluis, A.; Soares, C.J. Mechanical properties, shrinkage stress, cuspal strain and fracture resistance of molars restored with bulk-fill composites and incremental filling technique. J. Dent. 2015, 43, 1519-1528. [CrossRef]

40. Ilie, N.; Hickel, R. Investigations on a methacrylate-based flowable composite based on the SDR ${ }^{\mathrm{TM}}$ technology. Dent. Mater. 2011, 27, 348-355. [CrossRef]

41. Kim, R.J.; Kim, Y.J.; Choi, N.S.; Lee, I.B. Polymerization shrinkage, modulus, and shrinkage stress related to tooth-restoration interfacial debonding in bulk-fill composites. J. Dent. 2015, 43, 430-439. [CrossRef]

42. Belli, S.; Erdemir, A.; Ozcopur, M.; Eskitascioglu, G. The effect of fibre insertion on fracture resistance of root filled molar teeth with MOD preparations restored with composite. Int. Endod. J. 2005, 38, 73-80. [CrossRef]

43. Hormati, A.A.; Fuller, J.L. The fracture strength of amalgam overlying base materials. J. Prosthet. Dent. 1980, 43, 52-57. [CrossRef]

44. Versluis, A.; Tantbirojn, D.; Pintado, M.R.; Delong, R.; Douglas, W.H. Residual shrinkage stress distributions in molars after composite restoration. Dent. Mater. 2004, 20, 554-564. [CrossRef]

45. Kahler, B.; Swain, M.V.; Kotousov, A. Comparison of an analytical expression of resin composite curing stresses with in vitro observations of marginal cracking. Am. J. Dent. 2010, 23, 357-364. 